\title{
Trust deeds as 'constitutive charters' and the variation of trust provisions: a South Africanperspective
}

Francois duToit*

* Professor of Law, University of the Western Cape, South Africa.

\section{Abstract}

In this article, I assess the constitutive status accorded to trust deeds in Potgieter v Potgieter and Pascoal v Wurdeman, two recent South African judgments on trust variation. In particular, I analyse judicial condemnation of invoking reasonableness or fairness as freestanding norms to refashion the terms of trust deeds outside established common law or statutory norms; and I illustrate the place and role that equitable considerations play in South Africa as components of existing aggregated legal rules on trust variation. I also test the judicial approach taken to the foundational nature of trust deeds in the aforementioned judgments against the status accorded to trust instruments and documents by the Trust Property Control Act - a statute that regulates aspects of trust law in South Africa.

\section{Introduction}

South African trust scholars frequently describe trusts as 'creatures of document'. ${ }^{1}$ This denotes, of course, that the trust deed is a trust's founding document. ${ }^{2}$ The South African Supreme Court of Appeal concurred with this depiction when, in a seminal judgment on the abuse of a trust through trustees' disregard of the directives contained in its trust deed, it defined a trust deed as a trust's 'constitutive charter'. ${ }^{3}$

\section{South African trust scholars frequently describe trusts as'oreatures of document'}

In South Africa the term 'trust deed' is used generally to refer to thefounding document of an inter vivos trust created contractually by the trust founder and trustees. Accordingly, 'written agreement' is included in the definition of 'trust instrument' in the Trust Property

\footnotetext{
${ }^{1}$ Eg RP Pace and WN van der Westhuizen, Wills and Trusts (2011 - SI 15) B10.

${ }^{2}$ W Geach and J Yeats, Trusts Law and Practice (Juta 2007) 66.

${ }^{3}$ Land and Agricultural Bank of South Africa v Parker 2005 (2) SA 77 (SCA) [10].
} 
Control Act 57 of 1988 - a statute that regulates aspects of trust law in South Africa. The Act also lists 'testamentary writing' and 'court order' as trust instruments4-the former referring to a testator's will as the founding document of a testamentary trust, and the latter to a declaration of trust issued judicially. ${ }^{5}$

The Supreme Court of Appeal emphasized further trust deeds' foundational nature when, in the aforeentioned judgment on the abuse of the trust, it acknowledged that trustees cannot bind a trust contractually outside the provisions of its trust deed. ${ }^{6}$ The court consequently labelled a trust provision that demands a specified minimum number of trustees always to hold office as a 'capacity-defining condition': when a subminimum number of trustees are in office the trust suffers from incapacity that precludes the incumbent trustees from transacting, even through joint action, on its behalf. 7

The Supreme Court of Appeal emphasized further trust deeds foundational nature

This constitutive quality of trust deeds does not mean, however, that they are cast in stone, and are thus not open to variation. South African law permits the variation of trust deeds in terms of both the common law and statute. Established rules govern such variation, but sometimes these rules are obfuscated by courts and by litigants. This article evaluates two instances where such obfuscation occurred recently, and does so against the backdrop of the common law and statutory rules that govern the variation of trust deeds in South Africa.

\section{South African law permits the variation of trust deeds in terms of both the common law and statute}

Variation of the inter vivos trust at common lawand in terms of statute: general principles The fact that the trust deed of an inter vivos trust is cast in contractual form prompted the South African Supreme Court of Appeal (or Appellate Division, as it formerly was) to typify the agreement at hand as a contract for the benefit of a third party or stipulatio alteri. ${ }^{8}$ This characterization implies that the South African common law rules that govern the variation of a stipulatio alteri apply mutatis mutandis to the variation of an inter vivos

\footnotetext{
${ }^{4} \mathrm{~S} 1$.

${ }^{5}$ This article's analysis is confined by and large to the inter vivos trust.

${ }^{6}$ Parker (n 3) [10].

7 ibid, [11].

${ }^{8}$ Crookes v Watson 1956 (1) SA 277 (A); Hofer v Kevitt 1998 (1) SA 382 (SCA).
} 
trust. In particular, the common law permits the trust founder and trustees to vary the terms of the trust, and even to cancel the trust contract, consensually at any time prior to trust beneficiaries' acceptance of trust benefits. However, after the beneficiaries accepted trust benefits any variation to, or cancellation of, the trust contract requires also their consent. ${ }^{9}$ This is so because a beneficiary's acceptance of benefits, whether under a stipulatio alteri or an intervivos trust, occasions a vinculum iuris in the form of a right (either vested or contingent) between such beneficiary and the other parties to the contract. ${ }^{10}$ No such vinculum iuris exists prior to a beneficiary's acceptance; consequently, the trustees can agree with the trust founder in the pre-acceptance period even to a variation that has a negative effect on the benefits that will vest in the trust beneficiaries upon their eventual acceptance. Moreover, because variation of an inter vivos trust is a purely contractual matter, such beneficiaries cannot contest the variation by arguing that the trustees, through their consent to what the beneficiaries perceive as a detrimental variation, acted in breach of their fiduciary duties and, therefore, violated their fiduciary office. ${ }^{11}$

On the statutory front, section 13 of the Trust Property Control Act permits variation when a trust instrument contains any provision which brings about consequences that, in the opinion of the court, the trust founder failed to contemplate or foresee. Such provision must, however, also hamper the achievement of the founder's objectives; or prejudice the beneficiaries' interests; or conflict with the public interest. A trustee or any person who, in the opinion of the court, has a sufficient interest in the trust property can bring an application for variation under section 13 . The section empowers a court to delete or to vary any trust provision or to make in respect thereof any order which such court deems just, including an order effecting the substitution of trust property or an order terminating the trust. South African courts invoked section 13 recently to strike racial and gender limitations from charitable trust instruments upon ruling that these limitations occasioned unfair discrimination and, moreover, that the provisions that contained the limitations met section 13's jurisdictional fact regarding the founder's lack of contemplation or foresight as well as the section's criterion regarding conflict with the public interest. ${ }^{2}$

\section{Obfuscation of variation rules}

\footnotetext{
${ }^{9}$ Crookes (n 8) 285F; Hofer (n 8) 386G-387E.

${ }^{10}$ Crookes (n 8) 288A; Hofer (n 8) 387B.

${ }^{11}$ Hofer (n 8) 386G-H.

${ }^{12}$ Curators, Emma Smith Educational Fund v University of KwaZulu-Natal 2010 (6) SA 518 (SCA); Re Heydenrych Testamentary Trust 2012 (4) SA 103 (WCC).
} 
The significance of beneficiaries' acceptance of trust benefits for the consensual variation of an inter vivos trust renders it vital to establish whether such acceptance indeed occurred. A major beneficiary ${ }^{13}$ of full capacity can, of course, accept for himself, and a parent or guardian can accept on behalf of a minor or unborn beneficiary. ${ }^{14}$ An unequivocal expression of the intention to accept is required, but such expression can assume a variety of forms and its adequacy often depends on the circumstances at hand. ${ }^{15}$ In the Potgieter case, ${ }^{16}$ the Supreme Court of Appeal ruled recently that a trust founder accepted inter vivos trust benefits on behalf of his two minor children because such acceptance was conveyed by the trust deed's preamble ${ }^{17}$ and, moreover, because the minutes of a trustee meeting on the sale of trust property reflected that the trust founder represented the children in the deliberations on the proposed sale. ${ }^{18}$

Acceptance on the children's behalf having been established, it followed that their consent was required in respect of any consensual variation of the trust deed by the parties to the trust. A purported variation occurred in 2006 through an agreement between the founder and the trustees from which the two children (who had attained majority by that time) were excluded. The court a quo and the Supreme Court of Appeal ruled that the purported variation was invalid by reason of the children's non-participation therein. ${ }^{19}$ Such a ruling must result, of course, in the original trust deed being reinstated in unchanged form. However, the court a quo in the Potgieter case found such reinstatement unacceptable, and its ruling on this point occasioned the further pursuit of the matter before the Supreme Court of Appeal.

The lower court argued that the trust deed in unchanged form yielded inequitable results in light of significant changes that occurred with regard to the trust founder's personal circumstances subsequent to the original deed's execution in 1999. The trust deed originally designated the trust founder's two children (the appellants) as the trust's only capital beneficiaries. The trust founder divorced his wife (the appellants' mother) some

\footnotetext{
${ }^{13}$ In South Africa the age of majority is 18 years: Children's Act 38 of 2005, s 17.

${ }^{14}$ F du Toit, South African Trust Law: Principles and Practice (LexisNexis 2007) 52. S 14 of the Trust Property Control Act permits tutors or curators to consent to trust variation on behalf of beneficiaries under tutorship or curatorship, provided the variation is beneficial to the beneficiaries concerned.

${ }^{15}$ Du Toit (n 14) 52.

${ }^{16}$ Potgieter v Potgieter 2012 (1) SA 637 (SCA).

${ }^{17}$ ibid, [22].

${ }^{18}$ ibid, [26].

${ }^{19}$ ibid, [11], [28].
} 
four years after the deed's execution, and married the first respondent little more than a month thereafter. ${ }^{20}$ The second wife had two children (the fourth and fifth respondents) from a previous marriage. In 2006, the purported variation sought to terminate the appellants' status as the trust's only capital beneficiaries and included them merely as members of a group of potential capital beneficiaries along with the first, fourth, and fifth respondents. ${ }^{21}$ The trust founder followed this purported variation with the making of a new will in 2007; under the will all his assets were bequeathed to the trust. ${ }^{22}$ The court a quo reasoned that implementation of the trust deed in unchanged form would unfairly exclude the trust founder's second wife and the children from her first marriage from benefiting under the trust founder's deceased estate (he passed away in 2008) and that, given the stipulations of the 2007 will, such an outcome would be irreconcilable with the trust founder's final wishes regarding the distribution of his estate. ${ }^{23}$ The lower court accordingly ordered that one-fifth of the trust capital had to be awarded to each of the appellants as their exclusive property, while the other potential beneficiaries retained their rights in terms of the amended trust deed to the remaining three-fifths of the trust property. 24

The court a quo advanced section 13 of the Trust Property Control Act-particularly its stipulation that a court can issue 'any order which such court deems just' in a variation application -as the first ground for its departure from the trust deed's original prescripts. ${ }^{25}$ Secondly, the lower court, with reliance on jurisprudence of the South African Constitutional Court, ${ }^{26}$ argued that a court can refuse, on public policy and constitutional grounds, to order the implementation of a contractual provision that it deems unreasonable, and that this principle also extends to other spheres of South African private law. ${ }^{27}$ The lower court's ruling satisfied neither the appellants nor the respondents, and an appeal as well as a cross-appeal followed.

\footnotetext{
${ }^{20}$ ibid, [6], [7].

${ }^{21}$ ibid, [8].

22 ibid, [13].

${ }^{23}$ ibid.

${ }^{24}$ ibid, [2].

${ }^{25}$ ibid, [29].

${ }^{26}$ Particularly the judgment in Barkhuizen v Napier 2007 (5) SA 323 (CC).

${ }^{27}$ Potgieter (n 16) [31].
} 
The Supreme Court of Appeal, having dismissed the lower court's reliance on section 13 of the Act on the ground that no application for variation under this provision was before it, ${ }^{28}$ opined that the court a quo's invocation of public policy and constitutional grounds was 'fundamentally unsound' insofar as it misconstrued the Constitutional Court's jurisprudence that it advanced as a basis for its ruling. ${ }^{29}$ The Supreme Court of Appeal affirmed that South African law does not recognize reasonableness, and its corollary fairness, as free-standing requirements for the exercise of contractual rights; 30 nor do these constitute independent substantive rules that courts can employ to intervene in contractual relationships. ${ }^{31}$ The Supreme Court of Appeal opined that a grave danger associated with invoking reasonableness and fairness as free-standing norms, whether in contract law or in other private law spheres, is that it gives rise to 'intolerable legal uncertainty': 32 the principle of legality, fundamental to the rule of law, comes under threat when rules of law are made discretionary or subject to value judgements. 33

\section{The Supreme Court of Appeal affirmed that South African law does not reoognize reasonableness, and its corollary fairness, as free-standing requirements for the exercise of contractual rights}

Theprinipleoflegality,fundamental totherule oflaw, comes under threat when rules oflaw are made discretionary or subject to valuejudgements

The Supreme Court of Appeal ruled, in consequence of its aforementioned view, that the tenets of the common law had to be followed in casu: the variation of the trust deed was invalid for lack of consent by beneficiaries on whose behalf benefits be- stowed in terms of the deed were accepted earlier; hence the original provisions of trust deed, as contained in the deed prior to the purported variation, had to prevail. ${ }^{34}$ Therefore, the appellants were entitled to a declarator confirming such an outcome, and the Supreme Court of

\footnotetext{
${ }^{28}$ ibid, [30].

${ }^{29}$ ibid, [32].

${ }^{30}$ ibid.

${ }^{31}$ See also South African Forestry Co Ltd v York Timbers Ltd 2005 (3) SA 323 (SCA) [27].

${ }^{32}$ Potgieter (n 16) [34].

${ }^{33}$ See also Bredenkamp v Standard Bank of South Africa Ltd 2010 (4) SA 468 (SCA) [39].

${ }^{34}$ Potgieter (n 16) [37].
} 
Appeal upheld their appeal against the lower court's ruling. ${ }^{35}$

\section{Variation: reasonableness and legality}

The Supreme Court of Appeal's ruling in Potgieter on the place and role of legality as well as its consequent condemnation of invoking reasonableness and fair- ness as free-standing norms in South African private law in general, and in its trust law in particular, is correct. This standpoint does not mean, however, that reasonableness and fairness have no role to play with regard to South African trust law, and particularly with regard to the variation of trust deeds. After all, Roman-Dutch law, South Africa's common law to this day, was a:

'rational, enlightened system of law, motivated by considerations of fairness' ... [and] in virtually every aspect of Roman-Dutch law one will find equitable principles and remedies. 36

Nevertheless, the South African legal tradition demands that equitable considerations do not function as free-standing norms, but as components of aggregated judicially constructed or statutorily established legal norms.

\section{The South African legal tradition demands that equitable considerations do not function as free- standing norms, but as components of aggregated judicially constructed or statutorily established legal norms}

Indeed, a number of South African common law and statutory rules regarding the variation of trust instruments incorporate expressly reasonableness or faimess as part of such rules' normative structures. For example, a South African court recently invoked the common law rule against testamentary dispositions that conflict with public policy in order to vary a testamentary trust instrument through the striking-out of directives that occasioned 'unfair' discrimination. ${ }^{37}$ To this end the court relied, inter alia, on the comprehensive test for the determination of unfair discrimination laid down by the South

\footnotetext{
35 ibid, [37], [42].

${ }^{36}$ Le Roux v Dey (Freedom of Expression Institute and Restorative Justice Centre as Amici Curiae) 2011 (3) SA 274 (CC) [198]. See also Media24 Ltd v SA Taxi Securitisation (Pty) Ltd (Avusa Media Ltd and Others as Amici Curiae) 2011 (5) SA 329 (SCA) [74]; Potgieter v Kilian 1996 (2) SA 276 (N) 300D-F.

${ }^{37}$ Ex parte Minister of Education v Syfrets Trust Ltd 2006 (4) SA 205 (C).
} 
African Constitutional Court. ${ }^{38}$ Another example is the Sidelsky case ${ }^{39}$ where the court acknowledged the common law rule that permits a departure from testamentary trust provisions where compliance with the testator's directions became practically impossible or 'utterly unreasonable', provided that such was consequent on a change in circumstances subsequent to the will's execution that the testator failed to foresee. The South African legislature followed suit when it en-acted section 13 of the Trust Property Control Act by empowering a court to issue any order 'it deems just' in a variation application, provided the court formed the requisite opinion on the trust founder's lack of contemplation or foresight and, moreover, that, in applying an objective measure, the offending trust provision hampered the achievement of the founder's objectives; or prejudiced the beneficiaries' interests; or conflicted with the public interest. The legislature earlier decreed in similar vein in section 3 of the Immovable Property (Removal or Modification of Restrictions Act) 94 of 1965 that a court can remove any restriction imposed on immovable property (inter alia by a trust deed) and make any such further order 'it deems just', provided one of the section's requirements regarding the absence of beneficial occupation, use or enjoyment; or a negative effect on property value; or serving the public interest has been satisfied. In each of the aforementioned examples reasonableness or fairness constitutes a component part of an aggregated legal rule on trust variationcompliance with the totality of each rule's criteria or requirements-rather than invoking reasonableness or fairness as free-standing norms-ensures that legality and the rule of law is not compromised by the 'intolerable legal uncertainty' against which the Supreme Court of Appeal in the Potgieter case warned so strenuously. Moreover, it ensures that courts do not fall foul of the South African Constitution's prohibition against the arbitrary deprivation of property. 40

Significantly, the Supreme Court of Appeal's refusal in Potgieter to sanction the lower court's refashioning of the trust deed-and hence its affirmation of the original deed as the trust's constitutive charter-is aligned to the approach followed by South African courts with regard to judicial interference with testamentary trust provisions. In the J ewish Colonial Trust case, ${ }^{41}$ the court recognized the foundational nature of a will as a trust instrument

\footnotetext{
${ }^{38}$ In Harksen v Lane 1998 (1) SA 300 (CC).

${ }^{39}$ Ex parte Sidelsky 1983 (4) SA 598 (C) 601F.

${ }^{40}$ Constitution, s 25(1).

${ }^{41}$ Ex parte Jewish Colonial Trust Ltd: Re Estate Nathan 1967 (4) SA 397 (N).
} 
when it stated: 42

The Court cannot make, or re-make a testator's will for him; it cannot vary the will he has made. It cannot change the devolution of his estate as he has directed it, nor add to or subtract from the benefit he has conferred upon each of the beneficiaries. They must be content to take what they are given, when and on the terms on which it is given.

In Potgieter's aftermath a further blow for trust deeds as constitutive charters and, therewith, for adherence to legality with regard to trust variation was struck in the Pascoal case. 43 In casu discord between an inter vivos trust's trustees occasioned an application in terms of which one trustee faction (the respondents) requested, among others, that the trust deed's directive that all trustee decisions must be taken by majority vote should be limited to decisions taken at validly convened trustee meetings, whereas the other faction (the applicants) prayed an interim interdict that required unanimity in all decisions notwithstanding the trust deed's stipulations on trustee decision-making. ${ }^{44}$

The court, in denying the relief sought, opined that when litigants request a court to go beyond enforcing the terms of a contract, the source of the court's power to do so must be established: this is central to the rule of law that underpins the South African constitutional order. ${ }^{45}$ The court ruled that the applicants did not make out any case of a prima facie right to deviate from the trust deed on the basis of public policy or the Constitution, nor to vary it in accordance with section 13 of the Trust Property Control Act or on any other ground that would justify reading a provision on unanimous decision-making into the trust deed. 46 The court held in similar vein that the respondents advanced no ground in support of a deviation from the prescripts of the trust deed that would permit the court to impose the prerequisite of validly convened trustee meetings for trustee decisionmaking. ${ }^{47}$ In reaching this conclusion, the court emphasized the constitutive status of the trust deed insofar as:

[t]he intention of the creator and drafter of the trust deed as set out therein must

\footnotetext{
42 Jewish Colonial Trust (n 41) 408E-F.

${ }^{43}$ Pascoal v Wurdeman 2012 (3) SA 422 (GSJ).

44 ibid, [18].

45 ibid, [23].

46 ibid, [24], [26].

47 ibid, [28].
} 
be respected. 48

\section{Statutoryreoognitionoftrustdeedsas constitutivecharters}

The status of trust deeds as constitutive charters is bolstered by directives contained in the Trust Property Control Act. This statute was not conceived as a codification of South African trust law, and it merely regulates aspects of trust law. It is a relatively concise act, comprising only 27 sections. Nevertheless, no less than 13 of these sections contain directives pertaining to trust instruments or documents. Of particular relevance with regard to the variation of trust provisions (section 13 aside) are the Act's sections dealing with lodgement and access to trust instruments.

Section 4(1) of the Act demands lodgement of trust instruments with the Master of the High Court ${ }^{49}$ and section 4(2) instructs that, when a trust instrument is varied, the trustee must lodge the amendment or a certified copy thereof with the Master. Section 18 obliges the Master to release copies of documents relating to trust property to a trustee, his surety, his representative or any person who in the opinion of the Master has a sufficient interest in such document. Section 17 demands that a trustee remains custodian of all trust documentation for a period of five years from the termination of a trust; a trustee may destroy such documentation before the expiry of the five-year period only with the written consent of the Master.

The above-mentioned provisions ensure that trust deeds, whether original or varied, are assimilated into the South African state's legal-administrative machinery; they facilitate a measure of public access to such deeds; and they ensure that a constructive record of trust documentation-including the original and/or varied trust deed-is maintained even after a trust ceased to exist. Therefore, the Trust Property Control Act evinces clearly, in its regulation of matters pertaining to the administration of justice, the South African legislature's estimation of trust deeds as foundational documents.

\footnotetext{
48 ibid, [21].

49 The Master is a functionary charged with an array of tasks pertaining to, among others, the winding-up of deceased estates, the sequestration of insolvent estates, and the administration of trusts. Each of South Africa's nine provinces has at least one Master's office. S 3 of the Trust Property Control Act determines that, with regard to trust property other than property that is to be administered in terms of a testamentary writing, jurisdiction lies with the Master in whose area of appointment the greater or greatest portion of the trust property is situated.
} 
TheTrustProperty Control Actevinoesdearly, in its regulation of matters pertaining to the administration of justioe, theSouth Africanlegislaturesestimationoftrustdeedsasfoundational documents

\section{Conclusion}

The Potgieter and Pascoal judgments affirmed the status of trust deeds as constitutive charters in South Africa. The invalidity of the purported variation in the former case necessitated the Supreme Court of Appeal's ruling that the tenets of the common law on trust variation had to be followed and, consequently, that the original trust deed had to be reinstated in unvaried form. In the latter case the court, in ruling that it is not empowered to go beyond the terms of the trust deed as contended for by the litigants, emphasized that the stipulations of the original trust deed must be respected. Both courts were adamant that variation of trust provisions must conform to established common law or statutory rules; in the absence of such conformation a court is not empowered to order a departure from a trust deed's directives, particularly not on equitable grounds alone. This judicial approach is aligned fully with the foundational status accorded to trust deeds in the Trust Property Control Act, particularly insofar as the Act gives prominence to trust instruments and documents in its regulation of trusts in the legal-administrative operations of the Master's office.

The Potgieter and Pascoal judgments affirmedthestatusoftrustdeedsasconstitutive chartersinSouthAfrica

Franç ois du Toit is a Professor of Law at the University of theWestern Cape, South Africa. He holds a Doctor of Laws degree from Stellenbosch University. His research focuses on succession and trustlaw. The South African National Research Foundation awarded him a research rating in these disciplines in 2011. 